\title{
Cleaning house
}

\author{
With drug pricing a priority for the US Biden administration, the biotech industry must clean up its act: stop \\ profiteering from old products and stamp out anticompetitive practices.
}

ate last year, the US Trump

administration announced its Most

Favored Nation (MFN) model for drug pricing, aiming to align Medicare's 50 most prescribed drugs with their lowest international price. Despite wide bipartisan support for lowering US drug prices, MFN was immediately met by lawsuits from the Biotechnology Innovation Organization (BIO) and the Pharmaceutical Research and Manufacturers of America (PhRMA). Both industry associations claim MFN was unlawfully conceived and implemented. That may be correct, but the building legislative momentum means their efforts to stonewall drug price controls ultimately will fail. To win hearts and minds, industry must clean up long-standing profiteering practices on old products and proactively root out companies that cynically hike prices. Failure to do so will further damage the industry's reputation and potentially jeopardize valid arguments justifying premiums for new, innovative products.

The MFN model was a final-hour effort by a president already voted out of office to deliver on a campaign promise. Although it will not be implemented, the issue is not going away. The Biden administration plans to limit "abusively priced" drugs and negotiate lower prices for Medicare. It matters not that prescription drugs were less than $10 \%$ of the $\$ 3.8$ trillion spent on healthcare in 2019, nor that net prices for drugs (as opposed to list prices) in recent years have had only marginal increases. Legislation is coming.

Not all the blame for the drug pricing problem lies with drug companies. The problem encompasses the insurance industry, pharmacy benefit managers and all the middlemen taking their slice. Government initiatives have repeatedly failed to fix it. And in January, we learned that the might of private industry Amazon, Chase and Berkshire Hathaway also have failed.

Outrage from doctors, the public and media often focuses on the sticker shock associated with innovative drugs. For example, single treatment courses of gene and cell therapies Zolgensma and Zynteglo cost \$2.1 million and \$1.8 million, respectively. Similarly, the chimeric antigen receptor (CAR)-T cell therapy Tecartus costs $>\$ 300,000$ more than the 2019 median annual income of a US household. Bad actors like Martin Shkreli of Turing Pharmaceuticals, who jacked up the price of toxoplasmosis drug Daraprim (pyrimethamine) 60-fold overnight, also grab headlines.

But a far bigger, underappreciated problem is the industry-wide practice of hiking prices on old products and blocking generic and biosimilar competition. Time and time again, biotech companies circumvent the spirit of the Hatch-Waxman Act through patent filings and the courts. This is now the norm for doing business.

Humira (adalimumab) illustrates the typical template. When approved for rheumatoid arthritis in 2002, it received premium pricing as part of a groundbreaking wave of biologics targeting tumor necrosis factor- $\alpha$ and applicable to a host of inflammatory conditions (it is now cleared in nine more indications).

Yet when Humira's initial patent expired in 2016, biosimilar makers met a 'patent thicket' of over 100 additional claims AbbVie had erected around its jewel. AbbVie has since fought every biosimilar drugmaker in court before settling cases, one by one, for undisclosed amounts in return for commitments to keep biosimilars off the US market until 2023. Humira brought AbbVie $\$ 15$ billion in US revenue in 2019. The costs of the lawsuits and many settlements will not come close to that. This is textbook patent evergreening and 'pay for delay'. Amgen, Biogen and many other biotechs follow similar strategies for their franchises.

This first sin bleeds into a second. When there is no competition, innovators are free to raise prices with impunity. AbbVie does it; Amgen and Biogen do it; the majority of big biotech companies do it - even for aged products that should be off patent. Today's insulin analogs are more than 20 years old, and yet the prices consistently rise above inflation. A vial of Humalog was $\$ 21$ in 1999; in 2019, it was $\$ 332$. Whether the real cost of those drugs come down with rebates - as drugmakers argue - is almost irrelevant, as list prices determine a patient's copayment and are unreachable for the uninsured, and those issues are driving the anger on the ground.

So what is to be done?

First, biopharma companies must stop thwarting competition by exploiting exclusivity cracks in Hatch-Waxman and the Affordable Care Act (ACA), pursuing anticompetitive litigation in the courtroom decades after patents expire. It is not illegal on its face, but the government must make it so. The ACA grants 12 years of exclusivity for innovative biologics, but brands routinely flout exclusivity limits beyond that term. Lawmakers should amend legislation so that expiration of patent exclusivity for an old drug means just that. When patents expire, patients should have access to biosimilars or price cuts should be mandated to simulate the effects of competition - whichever is simpler.

Second, BIO should make a pledge for member companies. Companies must commit to not raise prices - net or list above inflation for off-patent products. That will soften the financial burden for patients.

And finally, BIO and industry must continue to call out the Martin Shkrelis of the world and brazen schemes attempting to shield patent estates from scrutiny (for example, Allergan's 2017 debacle signing over patent rights to sovereign Native American tribes).

Living up to these pledges will not be easy. Wall Street won't encourage it. Boardrooms aren't incentivized to do it. And lawyers thriving on litigation and anticompetitive pay-to-play deals will campaign against it.

But BIO and its members must find the courage to change. If BIO's 2016 name change to the Biotechnology 'Innovation' Organization means anything, it should be to serve and protect the interests of innovative biotech companies.

Continuing to turn a blind eye to profiteering and anticompetitive practices damages the reputation of innovative companies. And it is undermines valid arguments for why innovative drugs justify premiums. Now is the time for BIO and industry to clean house.

Published online: 1 February 2021 https://doi.org/10.1038/s41587-021-00832-8 